\title{
Effectiveness of a home-based physical therapy program in patients with chronic low back pain
}

\author{
Elena SîRBU1
}

\begin{abstract}
Aim: To demonstrate the effectiveness of a home-based physical therapy program on pain, spine mobility and quality of daily activities in patients with chronic low back pain (CLBP). We also want to show that patients who undergo this program decreased their intake in analgesic and anti-inflammatory drugs. Methods: 18 patients with chronic low back pain were assessed with the following tests: VAS pain scale, Schober's test and Rolland-Morris questionnaire. Acetaminophen and nonsteroidal anti-inflammatory drugs (NSAID) consumption was recorded. Over a period of six months all subjects participated in a 45 minutes home-based physical therapy program, three times per week. Before starting this intervention all patients were instructed and exercises were demonstrated in front of them by a physical therapist. Moreover, they received written brochures in order to exercise correctly at home. Follow-up examinations took place at baseline and six months later. Results: We obtained significant differences between pre- and post-intervention assessments of pain $(p=0.001)$, lumbar flexion $(\mathrm{p}=0.0001)$ and functional status $(\mathrm{p}=0.0005)$ in our group. Moreover, the number of patients who were taken analgesics decreased from $7(39 \%)$ to 5 patients (28\%). Likewise the number of patients who were taken anti-inflammatory drugs decreased from $11(61 \%)$ to 8 (44\%). Conclusion: The home-based rehabilitation program was effective in improving the ranges of active lumbar flexion and in decreasing the physical disability caused by low back pain, as well as in reducing the levels of pain. We note that a larger number of patients have given up to the intake of NSAIDs comparative to those who have given up to analgesics.
\end{abstract}

Key words: home-based rehabilitation program, low back pain, lumbar flexion, disability

\section{Rezumat}

Scop: Demonstrarea eficacității unui program de terapie fizicală efectuat la domiciliu asupra durerii, mobilității coloanei lombare și calității activităților zilnice la pacienții cu lombalgie cronică. De asemenea, dorim să arătăm că pacienții care au urmat acest program au redus aportul de analgezice și antiinflamatorii. Metode: 18 pacienți cu lombalgie cronică au fost evaluați prin intermediul următoarelor teste: scala VAS, testul Schober și chestionarul Rolland-Morris. A fost înregistrat consumul zilnic de acetaminofen și antiinflamatorii nesteroidiene. Toți pacienții au participat timp de 6 luni la un program, de 45 de minute, de terapie fizicală la domiciliu, trei ședințe pe săptămână. Înaintea începerii acestui program toți pacienții au fost instruiți, iar exercițiile au fost demonstrate, în fața lor, de către un terapeut. În plus, ei au primit brosuri cu scopul de a efectua la domiciliu cât mai corect exercițiile. S-a efectuat o evaluare inițială și, ulterior, încă o evaluarela 6 luni de la începerea programului. Rezultate: Am obținut diferențe semnificative între evaluările pre- și post-intervenție pentru durere $(p=0.001)$, flexia lombară $(p=0,0001)$ și funcționalitate $(p=0,0005)$. Mai mult de atât, numărul pacienților care utilizează analgezice a scăzut de la 7 (39\%) la 5 pacienți (28\%). De asemenea, numărul de pacienți care foloseau medicamente antiinflamatoare a scăzut de la 11 (61\%) la 8 (44\%). Concluzii: Aplicarea programului de terapie fizicală la domiciliu s-a dovedit a fi eficient în ameliorarea flexiei active lombare, a disabilității și în reducerea durerii. Un număr mai mare de pacienți au renunțat la consumul de medicamente antiinflamatorii comparativ cu cei care au renunțat la analgezice.

Cuvinte cheie: program de terapie fizicală la domiciliu, lombalgie, flexie lombară, disabilitate.

${ }^{1}$ Lecturer PhD, West University of Timisoara, Physical Education and Sport Faculty, Department of Kinetotherapy and Special Motricity; MD in Rheumatology at Milimed Clinic; e-mail: elena_sarbu@yahoo.co.uk 


\section{Introduction}

Low back pain is a disorder that affects in an acute, recurrent or chronic manner over $70 \%-80 \%$ of adult population, the maximum prevalence being around the age of 55-65 years, with a 5-10\% incidence at adult age. In U.S.A., 4 out of 5 persons present lumbar pains and in England 1.1 million examinations are annually recorded for the same cause $[1,2]$. In Romania the prevalence of low back pain in adults is high (62\%), second only to headaches $(79 \%)$ in the ranking of painful disorders [3].

This pathology causes high financial and social costs, being the most frequent cause of absenteeism and, at the same time, the most common cause of work capacity loss in persons aged less than 45 years, also generating significantly levels of disability compared to other musculoskeletal diseases [4].

The high frequency of lumbar spine disorders is explained through multiple incriminated risk factors, more and more current in our society: obesity, waist (larger than 1.70 in women and 1.80 in men), sedentary lifestyle, postural disorders, stress and last but not least, physical overload. Moreover, due to the ageing processes, the intervertebral disk degenerates and, under these conditions, at a certain point, minimum loads of the lumbar spine (lifting weights, twisting the torso) are enough to trigger acute or chronic pain [5].

In the management of low back pain patients, new methods of assessment and therapy, are needed which would limit the economic and social costs of this condition $[6,7]$.

Over time, various recovery methods for chronic low back pain have been studied, most of them being based on physical exercises (Williams, McKenzie programmes, Pilates method, Tai-Chi, etc.) [8]. Physical exercises are considered the best recovery method contributing both in ameliorating pain and in increasing abdominal and dorsal muscle tonus.

The purpose of this study was to demonstrate the effectiveness of a home-based physical therapy program on pain, function and quality of daily activities for chronic low back pain patients (CLBP). We also want to show that patients who undergo this program decreased their intake in acetaminophen and anti-inflammatory drugs.

\section{Material and methods}

The study included 18 patients ( 6 men and 12 women) aged 39 to 75 years diagnosed with chronic low back pain, defined as pain in the back, located between the last rib and the gluteal fold, with mechanical characteristics lasting more than 3 months. Patients were recruited from Milimed Clinic from September 2014 to October 2015. All patients were required to sign an informed consent form.

Subjects who had a history of back surgery, spinal tumor, spinal fracture, spinal stenosis or radiculopathy, fibromyalgia, inflammatory and infectious spinal diseases were excluded.

This study conformed to the principles outlined in the Helsinki Declaration.

Over a period of six months all subjects participated in a 45 minutes home-based physical therapy program, three times per week. Before starting this intervention all patients were instructed and exercises were demonstrated in front of them by a physical therapist. All patients practiced the exercises until they could perform them correctly. Moreover, they received written brochures in order to exercise at home. The exercises included:

- stretching exercises for the back, iliopsoas and hamstring muscles (5 repetitions of 20 -sec hold and 20 -sec of rest),

- strengthening exercises for the back, abdominal, gluteal and iliopsoas muscles (10 repetitions with a 5-sec hold);

Finally, all participants received ergonomic guidelines relevant to back problems, such as standing and sitting postures, reaching, kneeling, twisting, lifting, pushing and pulling.

The following assessment instruments were used: Schober's Test to assess the level of spine mobility, Visual Analogical Scale (VAS) for pain with scores from zero to ten and the Roland-Morris Questionnaire (RMQ). The RMQ is an assessment tool used for quantifying self-rated disability due to low back pain (LBP). This questionnaire contains 24 items, which reflect limitation indifferent activities of daily living attributed by the patient to LBP. The score ranges from 0 (absence of disability) to 24 (severe disability) [8].

Moreover, patients were instructed to record every day the non-steroidal anti-inflammatory (NSAID) and analgesic (acetaminophen) medication intake. 
All assessments were performed at baseline and 6 months after the initiation of this intervention.

Statistical analysis was performed using the Statistical Package for the Social Sciences (SPSS version 20). Student's $t$ test for paired data (twotailed) was used for the comparison of the mean values in the group of patients. A Levene's test was done before in order to assess the equality of variances. Values of $\mathrm{p}<0.05$ were considered significant.

\section{Results}

A total of 18 patients fulfilled inclusion criteria and completed the study. The general characteristics of the chronic low back pain patients are presented in table I.

Table I. General characteristics of patients with chronic low back pain

\begin{tabular}{lll}
\hline Parameter & & Value \\
\hline Age (years) (mean) & & $57 \pm^{`} 2.5$ \\
\hline Sex $^{\mathrm{b}}$ & Female & $12(67 \%)$ \\
& Male & $6(33 \%)$ \\
\hline${\text { BMI }\left(\mathrm{kg} / \mathrm{m}^{2}\right)^{\mathrm{a}}}$ & & $27.1 \pm^{`} 1.7$ \\
\hline Social environment (U) $^{\mathrm{s}}$ & Smoker & $14 / 4$ \\
\hline Smoke $^{\mathrm{b}}$ & Non-smoker & $4(12 \%)$ \\
& Ex smoker & $5(63 \%)$ \\
& 1 year & $4(25 \%)$ \\
\hline Duration of pain $^{\mathrm{b}}$ & 1-5 years & $9(50 \%)$ \\
& more than 5 & $5(28 \%)$ \\
& years & \\
\hline Fitness $^{\mathrm{b}}$ & Sedentary & $12(67 \%)$ \\
& Non sedentary & $6(33 \%)$ \\
\hline Profession $^{\mathrm{b}}$ & Employed & $14(78 \%)$ \\
& Unemployed & - \\
& Retiring & $4(22 \%)$ \\
\hline
\end{tabular}

$\mathrm{BMI}=$ Body Mass Index, $\mathrm{U}=$ urban environmment

${ }^{\mathrm{a}}$ Mean \pm SD, b Number [\%]

In our group the mean age of the females was 54 years and of males was 60 years. The overall mean age of patients was 57 years. We noticed a predominance of the lumbar pain in patients over 54 years. Most patients were smokers (63\%) and from urban areas.

Our results showed that in $50 \%$ of the participants the duration of low back pain was between 1-5 years. Also, in $22 \%$ of the patients the duration of the disease was 1 year and in $28 \%$ - more than 5 years.

The incidence of low back pain was higher in sedentary patients $(67 \%)$ compared with those non sedentary (33\%). Last but not least, chronic low back pain was more common among employees that carried physical labor.

The mean VAS score for pain had baseline values of $6.11 \pm 1.41$ and improved significantly at 6 months follow-up (5.17 \pm 1.38$)$ (Figure 1). Results obtained from the Rolland-Morris questionnaire revealed significant difference between pre- and postintervention measures ( $p=0.000)$ (Figure 2).

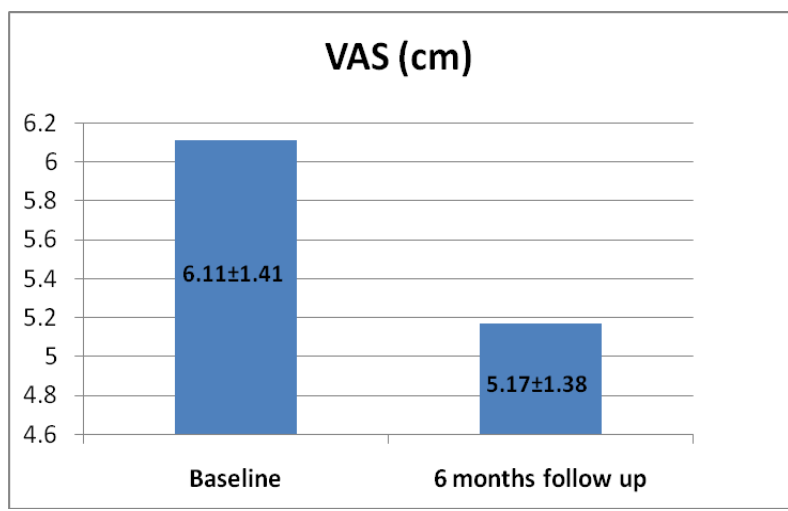

Figure 1. Evolution of pain at baseline and 6 months after the intervention

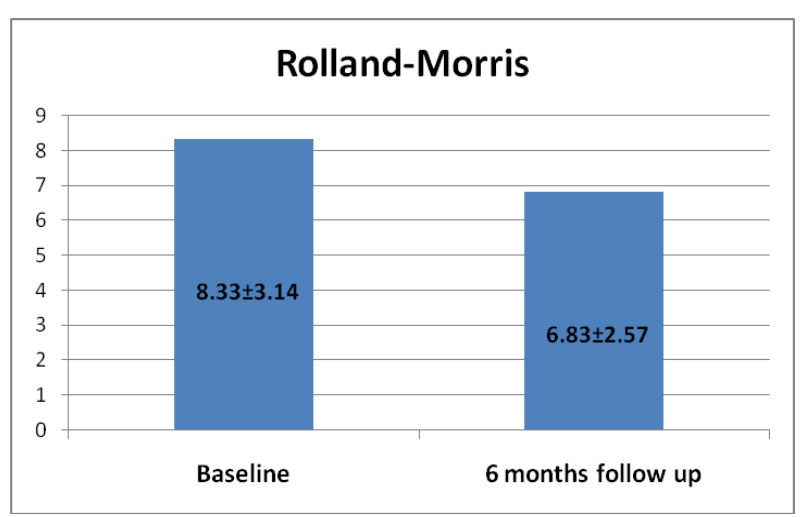

Figure 2. Evolution of functional status at baseline and 6 months after the intervention

Similar results were obtained regarding the extent of spine mobility as measured by Schober's Test $(p=0.000)$ (Table II) (Figure 3).

Table II. Clinical data at baseline and after 6 months

\begin{tabular}{lllc}
\hline Test & Baseline & $\begin{array}{l}\mathbf{6} \text { months } \\
\text { follow up }\end{array}$ & p \\
\hline VAS $(\mathrm{cm})$ & $6.11 \pm 1.41$ & $5.17 \pm 1.38$ & 0.001 \\
\hline $\begin{array}{l}\text { Schober } \\
(\mathrm{cm})\end{array}$ & $12.61 \pm 0.2$ & $13.5 \pm 0.18$ & 0.0001 \\
\hline $\begin{array}{l}\text { Rolland- } \\
\text { Morris }\end{array}$ & $8.33 \pm 3.14$ & $6.83 \pm 2.57$ & 0.0005 \\
\hline $\begin{array}{l}\text { Data are expressed as mean } \pm \text { standard deviation } \\
\end{array}$
\end{tabular}




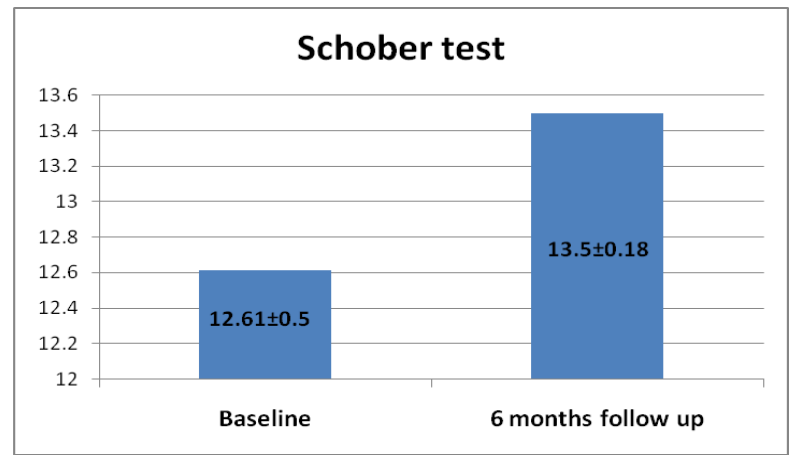

Figure 3. Evolution of spine mobility at baseline and 6 months after the intervention

The drug consumption was assessed by calculating the proportion of patients who had taken acetaminophen or NSAIDs. Acetaminophen intake was lower at the final assessment $(28 \%)$ and this finding was statistically different ( $p=0.03)$. Similar, a reduction in the percentage of patients using NSAIDs (to 44\%) was observed; this difference between assessments was statistically significant $(p=0.04)$ (Table III). We note that a larger number of patients have given up to the intake of NSAIDs comparative to those who have given up to analgesics.

\section{Discussion}

A sedentary lifestyle can lead to decreased abdominal and back muscle tone which cannot properly support the spine. Consequently, the forces supported by lumbar ligaments and spine bones are not equilibrated and mechanical strain may occur.

The current consensus is that therapeutic exercises are beneficial in the treatment of low back pain. Many rehabilitation programmes are aimed to reduce pain, to improve trunk flexibility, muscle strengthening, functional capacity and quality of life [9-12].

Furthermore, an increasing number of selfrehabilitation protocols are recommended by physical therapists. Some rehabilitation programmes can be performed at home through delivery of a booklet with exercises for low back pain, just as in this study $[13,14]$.

According to the literature, the efficacy of selfrehabilitation protocols seems to depend on the content, monitoring procedures and patient compliance with the treatment protocol $[15,16]$.
Table III. Acetaminophen and anti-inflammatory intake

\begin{tabular}{llll}
\hline Drug & $\begin{array}{l}\text { Baseline } \\
\text { (number } \\
\text { of patients) }\end{array}$ & $\begin{array}{l}\text { 6 months } \\
\text { follow up } \\
\text { (number of } \\
\text { patients) }\end{array}$ & $\mathbf{p}$ \\
\hline $\begin{array}{l}\text { Acetaminophen } \\
\text { intake }\end{array}$ & $7(39 \%)$ & $5(28 \%)$ & 0.03 \\
\hline $\begin{array}{l}\text { Anti- } \\
\text { inflammatory } \\
\text { intake }\end{array}$ & $11(61 \%)$ & $8(44 \%)$ & 0.04 \\
\hline
\end{tabular}

In the present study we demonstrate the effectiveness of a 6 months home-based physical therapy program in the management of chronic low back pain.

Thus, we obtained significant differences between pre- and post-intervention assessments of pain, trunk flexion and functional status in our group $(p<0.05)$. Moreover, the number of patients who were taken analgesics decreased from 7 (39\%) to 5 patients $(28 \%)$. Likewise the number of patients who were taken anti-inflammatory drugs decreased from $11(61 \%)$ to 8 (44\%) (Table III). Similar to our study, Hayden et al. published a review assessing the effectiveness of exercise in comparison to other treatments or no treatment at all and concluded that therapeutic exercise is effective in reducing pain and improving function in adults with chronic non-specific low back pain [17]. In addition, several studies have reported that programmes with stretching and strength-training exercises are most effective in reducing pain severity and improving functional outcomes [18-20].

On the other side, Ribeiro et al. observed the limited effectiveness of a back school program in the management of chronic nonspecific low back pain when compared to medical visits without educational intervention. They concluded that their program was only effective in terms of reducing the use of analgesic and anti-inflammatory medication but it was ineffective in the other quality of life domains, such as, pain, functional status, anxiety and depression. This limited effectiveness was perhaps due to the fact that psychosocial factors that may be directly associated with quality of life and hence with low back pain were not assessed (discontentment at work, low salaries, general worries etc.) [21]. 


\section{Conclusion}

The home-based rehabilitation program was effective in improving the ranges of active trunk flexion and in decreasing the physical disability caused by low back pain, as well as in reducing the levels of pain. A large number of patients who undergo this program decreased their intake in acetaminophen and anti-inflammatory drugs.

Home-based rehabilitation has evolved in recent years as a cost-effective and convenient alternative to traditional rehabilitation programs.

\section{References}

1. Walker B.F. (2000). The prevalence of low back pain: a systematic review of the literature from 1966 to 1998, Journal of Spinal Disorders, 13, 205-217.

2. Mihailov M., Cevei M., Popa D., Mihalcea S., Corha E., Cheregi I. (2006). Impactul balneo-fizioterapiei asupra disabilității la pacienții cu lombalgie inferioară, Revista Română de Reumatologie, vol. XV, 179-183.

3. Busse R., Schreyogg J., Smith P.C. (2008). Variability in healthcare treatment costs amongst nine EU countries results from the Health basket project, Health Econ, 17, 51-58.

4. Dalstra J.A.A., Kunst A.E., Borrell E. et al. (2005) Socioeconomic differences in the prevalence of common chronic disease: an overview of eight European countries. International Journal of Epidemiology,34,316-326.

5. Deyo R.A., Weinstein J.N. (2001). Low back pain. New Engl J Med, 344, 363-370.

6. Refshauge K.M., Maher C.G. (2006). Low back pain investigations and prognosis: a review. British Journal of Sports Medicine, 40(6), 494-8.

7. Weiner S.S., Nordin M. (2010). Prevention and management of chronic back pain, Best Practice Research Clinical Rheumatology, 24, 267-279.

8. Natour J. (2014). Pilates improves pain, function and quality of life in patients with chronic low back pain: a randomized controlled trial, Clinical Rehabilitation, 29(1), 59-68.

9. Liddle S.D., Baxter G.D., GraceyJ. (2004). Exercise and chronic low back pain: what works? Pain, 107,176-90.
10. Rainville J., Haritigan C., Martinez E., et al., Exercise as a treatment for chronic low back pain, Spine J, 4,106-15.

11. Staal J.B., Rainville J., Fritz J., Van Mechelen W., Pransky G. (2005). Physical exercise interventions to improve disability and return to work in low back pain: current insights and opportunities for improvement, Journal of Occupational Rehabilitation,15, 491-505.

12. Van der Velde G., Mierau D. (2000). The effect of exercise on percentile rank aerobic capacity, pain, and self-rated disability in patients with low back pain: a retrospective chart review, Archives of Physical Medicine and Rehabilitation, 81,145763.

13. Genet F., Poiraudeau S., Revel M. (2002). Effectiveness and compliance to a center-based short rehabilitation program with a home-based program for chronic low back pain, Annales de Réadaptationet de Médecine Physique, 45, 26572.

14. Kuukkanen T., Malkia E., Kautainen H., Pohjolainen T. (2007). Effectiveness of a home exercise program in low back pain: a randomized five-year follow-up study, Physiotherapy Research International, 12, 213-24.

15. Friedrich M., Gittler G., Halberstadt Y., Cermak T., Heiller I. (1998). Combined exercise and motivation program: effect on the compliance and level of disability of patients with chronic low back pain: a randomized controlled trial, Archives of Physical Medicine and Rehabilitation, 79, 475-87.

16. Kolt G.S., McEvoy J.F. (2003). Adherence to rehabilitation in patients with low back pain, Manual Therapy, 8, 110-6.

17. Hayden J.A., Van Tulder M.W., Malmivaara A., et al (2005). Exercise therapy for treatment of non-specific low back pain, Cochrane Database of Systematic Reviews, 20.

18. Hayden J.A., Van Tulder M.W., Tomlison G. (2005). Systematic review: strategies for using exercise therapy to improve outcomes in chronic low back pain, Annales of Internal Medicine, 142, 765-75.

19. Kankaanpaa M., Taimela S., Airaksinen O., et al (2004). The efficacy of active rehabilitation in chronic low back pain, Spine, 24, 1034-42.

20. Taylor N.F., Dodd K.J., Shields N., Bruder A. (2007). Therapeutic exercise in physioyherapy practice is beneficial: a summary of systematic reviews 2002-2005, Australian Journal of Physiotherapy, 53, 7-16.

21. Ribeiro L.H., Jennings F., Jones A., Furtado R., Natour J. (2008). Effectiveness of a back school program in low back pain, Clinical and Experimental Rheumatology, 26(1), 81-8. 